\title{
MAKNA ASOSIATIF DALAM PANTUN MERISIK PADA MASYARAKAT MELAYU BATU BARA
}

\author{
'Prayogo, ${ }^{2}$ Rodiyah Harahap, ${ }^{3}$ Rozanna Mulyani \\ 1,2,3 Universitas Sumatera Utara \\ Korespondensi: prayogokd@students.usu.ac.id
}

\begin{abstract}
Abstrak
Salah satu kajian dari bidang ilmu semantik adalah mengenai jenis makna dan salah satunya adalah jenis makna asosiatif atau makna asosiasi. Penelitian ini akan mendeskripsikan bagaimana masyarakat Melayu di Kabupaten Batu Bara memilih kata-kata serta mengasosiasikan secara tersirat kata-kata tersebut dengan benda dii luar bahasa kemudian dirangkai sedemikian rupa sehingga membentuk bait-bait pantun dan kemudian digunakan untuk menyampaikan maksud dan tujuan dalam acara merisik pada upacara adat perkawinan. Penelitian ini menggunakan metode deskriptif dan bentuk penelittiannya adalah penelitian kualitatif. Data yang digunakan dalam penelitian ini adalah pantun dalam acara merisik. Sumber data yang digunakan adalah buku dan datanya adalah data tertulis. Pemerolehan data dilakukan dengan cara mengumpulkan buku yang berkaitan dengan pantun merisik. Selanjutnya data yang diperoleh, kemudian dianalisis dengan teknik transkripsi, klasifikasi data dan analisis data dan terakhir dilakukan penarikan kesimpulan. Hasil analisis data yang diperoleh menemukan tiga aspek makna asosiasi yang dipakai yaitu asosiasi tinggi, asosiasi berat, asosiasi besar, asosiasi keterbukaan dan ketegasan.
\end{abstract}

Kata Kunci: makna asosiatif, pantun merisik, Melayu Batu Bara

\section{Abstract}

One study of the field of science is meaning and meaning are associative meaning or meaning of association. This study will describe how the Malay community in the Batu Bara Regency chose words and implicitly associated these words with objects outside the language arranged in a manner from several verses of the pantun bait and then to convey the meaning and purpose of the event. merisike during a wedding ceremony. This research uses descriptive methods and the research is qualitative research. The data in this study is the rhyme in the merisik program. Data sources which are books and data are written data. Data acquisition is done by collecting books mentioned with pantun merisik. Subsequent data were obtained, then analyzed by transcription techniques, data data and data analysis and conclusions were finally made. The results of data analysis obtained from three meaning factors used are associations, associations, associations, associations of openness and firmness.

Keywords: associative meaning, pantun merisik, Batu Bara Malay 


\section{PENDAHULUAN}

Upacara perkawinan merupakan upacara yang sangat sakral untuk dilakukan, hal ini dikarenakan seluruh manusia pasti mengalami fase pernikahan ini. Kata sakral juga dipengaruhi oleh pemikiran manusia yang didapatkan dari ajaran-ajaran agama masingmasing individu. Agama mengajarkan untuk selalu menjaga rumah tangga yang telah dibina. Dalam Kamus Besar Bahasa Indonesia, kata sakral memiliki makna suci ataupun keramat.

Semua suku di Indonesia memiliki upacara adat dalam perkawinannya masingmasing, setiap suku memiliki ciri pembedanya untuk menandainya. Ciri pembeda ini ditujukan untuk mempermudah mengenali bagi masyarakat pengguna adat tersebut. Salah satu suku yang memiliki tata cara upacara adat pernikahan adalah suku Melayu. Tata cara upacara perkawinan dalam masyarakat Melayu sangat banyak tahapannya, mulai dari merisik, jamu sukut, merintis dan merisik, merisik besar, meminang, ikat janji, mengantar bunga sirih, berinai, akad nikah, penyambutan pengantin laki-laki, upacara persandingan, upacara tepung tawar, upacara nasi hadap-hadapan, upacara makan nasi, adat berjulang, upacara serah terima pengantin laki-laki, mandi bedimbar, meminjam pengantin dan seterusnya.

Setiap tahapan upacara perkawinan suku Melayu tersebut, masyarakat penggunanya selalu menggunakan pantun untuk menyampaikan maksud dan tujuan dalam setiap tahapannya. Pantun ini disampaikan oleh seseorang yang dianggap mampu dan memiliki kemampuan yang mumpuni untuk menyampaikan maksud dan tujuan melalui pantun. Keluarga biasa mempercayakan penyampaian pantun ini oleh telangkai. Telangkai inilah yang berkomunikasi selama tahapan upacara adat perkawinan suku Melayu.

Kamus Besar Bahasa Indonesia memaknai pantun ini sebagai sajak pendek, tiaptiap kuplet biasanya empat baris (a-b-a-b) dan dua baris yang dahulu biasanya untuk tumpuan saja. Pendapat lain juga dikemukakan oleh Effendy (2004:143) yang menyatakan pantun sebagai puisi lama yang terdiri atas 4 larik dengan rima akhir a-b-a-b. Setiap larik biasanya terdiri atas 4 kata, larik 1-2 merupakan sampiran, larik 3-4 merupakan isi. Secara etimologis, pantun identik dengan seperangkat kosakata yang disusun dengan merujuk kepada sejumlah kriteria konvensional dan secara terminologi ada beberapa pengertian pantun disampaikan oleh beberapa pakar (Sinar 2011:9)

Karena tahapan upacara adat perkawinan Melayu sangat banyak, maka penulis akan mempersempit kajian dalam penelitian ini. Dalam penelitian ini hanya akan membahas salah satu tahapan saja yaitu tahapan Upacara Merisik. Merisik merupakan langkah pertama sebagai proses menjodohkan antara jaka dan dara yang diawali oleh pertemuan antara perwakilan dari pihak jaka dengan orang tua si dara. Pertemuan pertama ini merupakan hal yang paling penting untuk menghargai orang tua dari pihak si dara. Falsafah Melayu mengatakan jika ingin meminang anaknya, pinanglah terlebih dahulu ibu dan bapaknya (Sinar 2011:54). Falsafah tersebut bermakna bahwa pandangan dan restu orang tua sangat penting untuk membuat keputusan yang besar seperti perkawinan.

Selain merisik, di dalam tahapan ini juga ada proses merintis yaitu proses untuk menetukan kedudukan si dara. Maksudnya adalah untuk mengetahui apakah si dara sudah ada meminang atau belum. Proses merintis ini juga untuk mengetahui bagaimana seluk beluk dari keluarga si dara atau melihat bibit, bebet dan bobotnya. Pihak jaka akan memilih beberapa perwakilan dari keluarga mereka sebelum bertandang ke rumah si dara. 
Perwakilan yang telah ditunjuk tadi akan dipilih kembali perwakilan yang dianggap mampu menyampaikan dan menyusun kata-kata terutama dalam menyusun kata-kata tersirat yang akan disampaikan tentang maksud dan tujuan mereka datang.

Ketika sudah sampai ke rumah pihak si dara akan berkomunikasi tentang kehidupan keluarga kedua belah pihak sembari menikmati makanan yang disuguhkan oleh pihah si dara termasuk si dara yang menghidangkan makanan kepada pihak si jaka. Kesempatan inilah yang digunakan oleh pihak si jaka untuk melihat paras si dara yang akan dipersunting oleh si jaka. Pada kesempatan ini jugalah pihak si jaka mengutarakan maksud dan tujuan mereka datang ke rumah pihak si dara. Tahap merintis inilah yang digunakan oleh pihak si jaka untuk mengungkapkan keinginannya untuk memetik bunga di taman untuk si kumbang jika belum ada yang memminangnya. Maksud dan tujuan dari pihak si jaka disampaikan dalam bentuk pantun.

Contoh:

Kalau gugur buah setandan

Sampai ke tanah baru tegolek

Kami bersyukur kepado Tuban

Datang kami disambut baek

Kabung enau tebang satu

Tebang seklai dengan sigainyo

Tinggi gunung tinggi lagi harapanku

Harapan dalam tutur katonyo

Sudah lamo langsatnyo condong

Dahannyo robah ke ampaian

Sudab lamo niat dikandung

Baru sekarang disampaikan

Dari tiga contoh di atas, dapat kita lihat bagaimana masyarakat Melayu mengasosiasikan kenginannya yang tinggi dengan mengibaratkan dengan sesuatu yang berat, besar dan tinggi seperti pada kata Tinggi gunung tinggi lagi harapanku yang mengasosiasikan tingginya hasrat dengan gunung. Seperti yang kita ketahui gunung itu memiliki posisi geografis yang tinggi sehingga dilambangkan sebagai harapan yang tinggi. Pantun dalam proses merisik inilah yang akan dianalisis dari segi makna asosiatifnya.

\section{METODE}

Pantun akan dianalisis menggunakan teori semantik khususnya adalah teori makna asosiatif. Mengapa menggunakan teori semantik karena semantik merupakan ilmu linguistik yang mempelajari tentang makna seperti yang disampaikan oleh Verhar (2008:13) yang menyatakan semantik adalah cabang dari linguistik yang membahas arti atau mkana. Pateda (2001:7) juga mengungkapkan semantik adalah subdisiplin linguistik yang membicarakan makna.

Makna asosiatif merupakan makna yang sama dengan perlambang-perlambang yang digunakan oleh suatu masyarakat bahasa untuk menyatakan konsep lain (Chaer 2013:72). Sementara itu Tarigan (2009:90) menyatakan pendapatnya tentang makna asosiatif ini, yaitu ada perubahan makna yang terjadi akibat persamaan sifat dan perubahan tersebut dinamakan asosiasi. Dengan demikian makna asosiasi ini lebih menjurus kepada nilai moral dan pandangan hidup dari masyarakat pengguna bahasa itu. 
Makna asosiatif ini juga termasuk makna konotatif atau makna yang tidak sebenarnya. Mengapa dikatakan demikian? Karena jika dilihat dari strrukturnya makna konotatif ini menggunakan kiasan untuk menggabrakan sesuatu.

Leech (1981) membagi makna menjadi makna konseptual dan makna asosiatif. Makna konseptual adalah makna dimiliki oleh leksem terlepas dari konteks atau asosiasi apapun. Kata "jasmine" memiliki makna konseptual; tanaman yang memiliki bunga dengan aroma yang manis, sejenis bunga berwarna putih dan kata "rumah" memiliki makna konseptual; bangunan tempat tinggal manusia. Jadi, makna konseptual sebenarnya sama dengan makna leksikal, makna denotatif, atau makna kognitif.

Makna asosiatif adalah makna yang memiliki leksem atau kata yang berkenan dengan adanya hubungan kata tersebut dengan sesuatu yang berada diluar bahasa (Kasopa 2017:3). Makna asosiatif juga digunakan oleh suatu masyarakat bahasa untuk menyatakan konsep lain, yang mempunyai kemiripan dengan sifat, keadaan, atau ciri yang ada pada konsep asal kata atau leksem tersebut.

Penyelesaian penelitian ini menggunakan metode deskriptif. Moleong (2013:6) berpendapat tentang pengertian penelitian kualitatif yaitu penelitian yang bermaksud untuk memahami fenomena tentang apa yang dialami oleh subjek penelitian misalnya perilaku, persepsi, motivasi, tindakan, dan lain-lain, secara holistik dan dengan cara deskripsi dalam bentuk kata-kata dan bahasa, pada suatu konteks khusus yang alamiah dan dengan memanfaatkan berbagai metode alamiah. Sugiyono (2010:2) berpendapat bahwa metode penelitian merupakan cara ilmiah untuk mendapatkan data dengan tujuan dan kegunaan tertentu. Sementara itu Nawawi (2012:67) memberiikan pandangannya tentang metode deskriptif, Nawawi menyatakan metode deskriptif dapat diartikan sebagai prosedur pemecahan masalah yang akan diselidiki dengan cara menggambarkan/melukiskan keadaan subyek/obyek penelitian pada saat sekarang berdasarkan fakta-fakta yang tampak, atau sebagaimana adanya.

Dalam penelitian ini, data diperoleh dari buku dan juga data pendukung lain, setelah data didapatkan kemudian dilakukan pengecekan keabsahan data yang telah diperoleh. Pengecekan keabsahan data ini bertujuan untuk memastikan data tersebut benar-benar pantun yang dipakai oleh masyarakat Melayu Batu Bara dalam upacara adat perkawinan khususnya upacara adat merintis dan merisik. Setelah data lolos pengecekan, langkah selanjutnya adalah melakukan analisis menggunakan teori yang telah ditentukan untuk menghasilkan data makan asosiatif dalam pantun merintis dan merisik.

\section{HASIL DAN PEMBAHASAN}

Bila dalam suatu keluarga terdapat seorang dara yang sudah dewasa secara mental dan ada seorang jaka yang tertarik dengannya, maka si jaka akan memberitahukan kepada orang tuanya. Setelah diceritakan maka orang tuanya ataupun sanak terdekat dari si jaka akan secara langsung menemui pihak si dara. Jika pihak si dara setuju dengan calon yang dikehendaki oleh si jaka maka pihak si jaka akan meminta salah satu dari pihak si dara untuk merisik. Sebelum memasuki era modern, masyarakat pada zaman dahulu menggunakan jasa penghulu telangkai untuk merisik. Penghulu telangkai digunakan sebagai mediator antara pihak si dara dan si jaka untuk menyampaikan maksud dan tujuan. Tetapi jika sudah menggunakan penghulu telangkai maka kemungkinan besar pinangan dari pihak si jaka akan diterima. 
Setelah dapat dipastikan kemungkinan pinangan dari pihak si jaka akan diterima, penghulu telangkai akan berbicara kepada kedua orang tua dari kedua pihak dengan cara yang sangat diplomatis. Namun begitu, pihak si dara tidak begitu saja menerima pinangan yang disampaikan oleh penghulu telangkai dari pihak si jaka, tetapi pihak si dara akan melakukan pengintaian terhadap calon dari si dara terlebih dahulu. Tugas untuk mengintai si jaka ini akan dibebankan kepada orang tua ataupun kepada orang yang dianggap dekat kepada si jaka. Apabila kedua orang tua dari pihak si dara setuju maka akan segera disampaikan kepada penghulu telangkai, tetapi dengan bahasa kiasan dan tidak dikatakan secara langsung menerima calon dari si dara. Setelah menerima informasi yang baik ini, maka penghulu telangkai bergegas untuk menyampaikannya kepada kedua orang tua si jaka.

Proses merisik diawali dengan pantun yang sampaikan oleh pihak dari si jaka dan selanjutnya, pihak si dara akan membalas pantun yang disampaikan oleh Penghulu Telangkai dari pihak laki-laki. Pantun yang awal sekali disampaikan adalah apa maksud dan tujuan pihaK si jaka datang ke rumah pihak si dara seperti yang tergambar dalam pantun di bawah ini:

Kalau gugur buah setandan

Sampai ke tanah baru tegolek.

Kami bersyukur kepada Tuban

Datang kami disambut baek

Kabung enau tebang satu

Tebang sekali dengan sigainyo

Tinggi gunung tinggi lagi harapan ku

Harapan dalam tutur katonyo

Sudah lamo langsatnya condong

Dabanyo robah ke ampaian

Sudah lamo niat dikandung

Baru sekarang disampaikan

Dari Pauh singsah Pematang

Singgah merapat papan kemudi

Dari jauh kami datang

Karena tuan yang baek budi

Berapo tinggi pucuk pisang

Tinggi lagi asap api

Berapo tinggi kampung lalang

Tinggi lagi harapan hati

Bosar api Toluk Gadung

Anak buayo menggonggongg bangkai

Niat hati nak poluk gunung

Apokan dayo tangan tak sampai

Analisis pantun pertama

Kalau gugur buah setandan

Sampai ke tanah baru tegolek.

Kami bersyukur kepada Tuban

Datang kami disambut baek. 
Pihak si jaka sangat bersyukur dan begitu lega ketika kunjungan mereka disambut sangat baik. Kelegaan itu mereka asosiasikan dengan kalimat kalau gugur buab setandan berdasarkan ciri ini buah yang menggunakan satuan setandan adalah buah pisang. Buah pisang jika sudah besar tandanannya pasti bobot yang cukup berat akan gugur dengan cara condong secara sedikit-demi sedikit dan akan berhenti ketika sudah sampai ketanah seperti yang disampaikan baris kedua sampai ke tanah baru tegolek. Begitu pula dengan pihak si jaka yang mempunyai niat untuk memetik bunga di taman, ketika belum tersampaikan maka akan selalu gelisah. Pihak si jaka sangat bersyukur ketika niat mereka disambut baik seperti yang disampaikan pada baris keempat datang kami disambut baek. Besarnya harapan pihak si jaka diulangi juga pada pantun bait ketiga dan bait kelima.

Berapo tinggi pucuk pisang

Tinggi lagi asap api

Berapo tinggi kampung lalang

Tinggi lagi harapan hati

Pada contoh pantun kedua ini mengungkapkan begitu tinggi harapan dari pihak si jaka seperti yang diungkapkan pada baris keeempat tinggi lagi harapan hati. Baris pertama pada pantun tersebut menyebutkan berapo tinggi pucuk pisang artinya pucuknya masih dapat dijangkau oleh manusia sebagai pembanding dimunculkan lagi pada baris kedua tinggi lagi asap api seperti kita ketahui asap dari sebuah pembakaran akan selalu membumbung tinggi sampai ke atmosfir, hal ini digunakan untuk mengasosiasikan begitu tinggi harapan dari pihak si jaka.

Setelah pihak si jaka selesai menyampaikan maksud dan tujuannya menggunakan pantun, selanjutnya pihak si dara akan membalasnya dengan menggunakan pantun juga berikut pantun yang disampaikan oleh Penghulu Telangkai pihak si dara.

Perabu kolek ke Kualo Tanjung

Syarat bermuat tali temali

Salam tersusun sirih junjung

Apo hajat sampai kemari?

Tidak pornah rotan merentang

Kayu cendano dijilat api

Tidak pornah tuan bertandang

Tontu ado maksud di hati

Malam-malam pasang pelito

Pelito dipasangg di atas poti

Kalau sudah bagai dikeato

Silo torangkan hajat di bati

Tumbuk lado di atas para

Ado kasut simpan dipoti

Topuk dado taanyo selera

Apo maksud di dalam hati

Analisis pantun kedua

Pada pantun yang terdapat di bait kedua, dapat dilihat bagaimana pihak si dara mempertanyakan maksud dan tujuan dengan pertanyaan seperti pada baris ketiga tidak pornah tuan bertandang. Sebelum pada baris ketiga, penghulu telangkai terlebih dahulu mengasosiasikannya pada baris pertama yaitu tidak pornah rotan merontang. Maknanya adalah sesuatu hal yang tidak pernah dilakukan dan tiba-tiba dilakukan maka akan 
menimbulkan sebuah pertanyaan, seperti halnya tumbuhan rotan yang lazimnya tidak pernah tumbuh lurus tiba-tiba tumbuh merentang atau lurus.

Malam-malam pasang pelito

Pelito dipasang di atas poti

Kalau sudah bagai dikato

Silo torangkean hajat di bati

Pantun bait yang keempat ini pihak si dara masih bingung dengan kedatangan pihak si jaka seperti yang dituliskan pada baris keempat silo torangkan hajat di hati. Kata pada baris keempat ini diasosiasikan pada baris pertama pada pantun ini yaitu malammalam pasang pelito yang bermakna jika kita berada dalam kegelapan silahkan untuk memasang pelita supaya terang dan kelihatan di sekelilingnya, seperti halnya jika ada hajat di hati silahkan utarakan agar terdapat kejelasan dan tidak terjadi kebingungan.

Tumbuk lado di atas para

Ado kasut simpan di poti

Topuk dado tanyo selera

Apo maksud di dalam hati

Pada bait keempat ini pihak si dara masih menanyakan kejelasan maksud kedatangan dari pihak si jaka, pada pantun bait keempat ini sudah lebih tegas pertanyaan dari penghulu telangkai pihak si dara seperti pada baris ketiga topuk dado tanyo selera. Baris ketiga ini diasosiasikan pada baris pertama yaitu tumbuk lado di atas para, tumbuk lada adalah sejenis alat untuk menumbuk buah pinang untuk menyirih. Pada pantun ini tampak ketegasan pertanyaan dari penghulu telangkai dengan pengasosiasian tumbuk lada yang digunakan dengan sekuat tenaga.

\section{PENUTUP}

Berdasarkan hasil analisis terhadap makna asosiatif dalam pantun merisik pada masyarakat Melayu Batu Bara ditemukan empat asosiasi yang terdapat dalam pantun merisik yaitu:

1. Asosiasi tinggi

Pada asosiasi yang pertama ini ada dijumpai asosiasi tinggi dalam pantun merisik seperti pada bait berikut

$$
\begin{aligned}
& \text { Berapo tinggi pucuk pisang } \\
& \text { Tinggi lagi asap api } \\
& \text { Berapo tinggi kampung lalang } \\
& \text { Tinggi lagi harapan hati }
\end{aligned}
$$

Kabung enau tebang satu

Tebang sekali dengan sigainyo

Tinggi gunung tinggi lagi harapan ku

Harapan dalam tutur katonyo

Pantun tersebut mengasosiasikan harapan yang tinggi dengan kalimat pantun pada baris kedua yaitu tinggi lagi asap api dengan kalimat pembanding pada baris pertama berapo tinggi pucuk pisang. Artinya tingginya pucuk pisang dapat dijangkau tetapi tidak dengan asap yang membumbung kelangit yang tidak dapat dijangkau, setinggi itulah harapan dari pihak si jaka.

2. Asosiasi besar 
Asosiasi yang kedua dijumpai asosiasi besar dalam pantun merisik seperti pada bait pantun berikut:

Kalau gugur buah setandan

Sampai ke tanah baru tegolek.

Kami bersyukur kepada Tuhan

Datang kami disambut baek

Sudah lamo langsatnya condong

Dahanyo robah ke ampaian

Sudab lamo niat dikandung

Baru sekarang disampaikan

Pada kedua bait pantun di atas mengasosiasikan besarnya harapan dari pihak si jaka secara tersirat. Dapat kita lihat pada baris pertama bait pertama yaitu kalau kalau gugur buah buah setandan yang dapat diartikan dengan buah pisang yang sudah besar dan secara perlahan akan condong jatuh ketanah. Apabila harapan yang besar telah tersampaikan maka akkan timbul kelegaan seperti yang tersirat pada baris kedua yaitu sampai ke tanah baru tegolek.

3. Asosisasi keterbukaan dan ketegasan

Pada asosiasi ketiga dijumpai asosiasi keterbukaan dan ketegasan dalam pantun merisik pada masyarakat Melayu Batu Bara seperti pada bait pantun berikut:

Malam-malam pasang pelito

Pelito dipasangg di atas poti

Kalau sudah bagai dikato

Silo torangkan hajat di hati

Bait pantun diatas dapat kita lihat asosiasi keterbukaan yang disampaikan oleh penghulu telangkai seperti yang tampak pada baris keempat yaitu silo torangkan hajat di hati artinya pihak si dara sudah mulai terbuka kepada pihak si jaka dengan mengasosiasikannya pada baris pertama yaitu malam-malam pasang pelito pada baris ini dapat kita maknai kepada sesuatu hal yang masih gelap atau yang belum tau apa-apa kemudian diberitahukan dengan asosiasi memasang lampu pelita.

Tumbuk. lado di atas para

Ado kasut simpan di poti

Topuk dado tanyo selera

Apo maksud di dalam hati

Pada bait keempat ini pihak si dara masih menanyakan kejelasan maksud kedatangan dari pihak si jaka, pada pantun bait keempat ini sudah lebih tegas pertanyaan dari penghulu telangkai pihak sii dara seperti pada baris ketiga topuk dado tanyo selera. Baris ketiga ini diasosiasikan pada baris pertama yaitu tumbuk lado di atas para, tumbuk lada adalah sejenis alat untuk menumbuk buah pinang untuk menyirih. Pada pantun ini tampak ketegasan pertanyaan dari penghulu telangkai dengan pengasosiasian tumbuk lada yang digunakan dengan sekuat tenaga

Banyak hal yang dapat diungkapkan dari kearifan lokal dari masing-masing suku yang ada di Indonesia. Tujuan dalam pengungkapan makna yang ada di balik kearifan lokal ini adalah untuk memperkenalkan kearifan lokal kepada generasi muda agar mereka dapat memahami adat istiadat budayanya. Selain itu dengan banyaknya pembahasan tentang budaya dan kearifan lokal ini akan mencegah kepunahan dari kebudayaan asli dari suku yang ada di Indonesia. 


\section{DAFTAR RUJUKAN}

Alwi, Hasan dkk, Tata Bahasa Buku Bahasa Indonesia. Jakarta: Balai Pustaka, 2010

Chaer, Abdul, Pengantar Semantik Bahasa Indonesia. Jakarta: Rineka Cipta, 2002.

Chaer, Abdul, Linguistik Umum. Jakarta: Rineka Cipta, 2007.

Kasopa, Jeaneta Krisya, Makna Asosiatif dalam Kitab Mazmur. Manado: Universitas Sam Ratulangi, 2017.

Kridalaksana, Harimurti, Kamus Linguistik. Jakarta: Gramedia Pustaka, 2009.

Leech, Geoffrey, Semantics The Study of Meaning. Second ed. Great Britain: Penguin Books, 1981.

Mahsun, Metode Penelitian Bahasa. Jakarta: Rajawali Perss, 2012.

Moleong, Lexy, Metodologi Penelitian Kualitatif. Bandung: Remaja Rosdakarya, 2013.

Mwihaki, Alice, Meaning as Use : a Functional View of Semantics and Pragmatics, 2004.

Nawawwi, Metode Penelitian Bahasa. Jakarta. Rajawali Perss, 2012.

Pateda, Mansoer, Semantik Leksikal. Jakarta: Rineka Cipta, 2001.

Sinar, Tengku Silvana, Kearifan Lokal Berpantun dalam Perkawinan Adat Melayu Batu Bara. Medan: USU Press, 2011.

Sugiyono, Metodologi Penelitian Kuantitatif Kualitatif Dan R \& D. Bandung: Alfabeta, 2010. 